\title{
SUCCESS AND FAILURE: FRANTZ FANON AND LAMINE SENGHOR AS \\ (FALSE) PROPHETS OF DECOLONIZATION?
}

\section{DAVID MURPHY}

Frantz Fanon has often been hailed as the great prophet of decolonization, the seer who predicted the downfall of the great European empires as well as the pitfalls awaiting the newly independent countries of Africa and Asia. But at the same time, his most severe critics have accused his work of providing intellectual/political cover for some of the worst excesses of these newly independent regimes. The critical dispute between Christopher Miller and Neil Lazarus exemplifies the opposing views regarding Fanon's historical foresight (or lack of it): for Miller, Fanon's celebration of anti-colonial nationalism and violence acts as a defence of what would later become the authoritarian regimes of the likes of Guinea's Sékou Touré; whereas for Lazarus, Fanon's errors of judgement do not undermine his prescience, in particular, in warning against the dangers of the 'big man' school of politics and its potential to derail the radical project of anti-colonial nationalism. ${ }^{1}$

But what processes are involved in deeming Fanon to have been a success or a failure? David Macey's contextualising approach to the life of Fanon helps us address this question. For one of the many strengths of his biography is his ability to place Fanon's work within the context of its time with all the inherent messiness and limitations faced by an individual trying to make sense of the era in which he lived. Macey's work is situated within the same postcolonial historical tradition as C. L. R James's The Black Jacobins, his groundbreaking history of Toussaint Louverture and the Haitian revolution in which the contribution of the 'heroic' individual is recognized but always clearly positioned within the particular 
constraints and possibilities of his/her era. As James famously stated in the preface to his volume:

Great men make history, but only such history as it is possible for them to make. Their freedom of achievement is limited by the necessities of their environment. To portray the limits of those necessities and the realisation, complete or partial, of all possibilities, that is the true business of the historian. ${ }^{2}$

The aim of this article is to build on Macey's contextualizing work - his exemplary exploration of the 'limits of those necessities and the realisation, complete or partial, of all possibilities' - in order to think in a more general fashion about the processes involved in deeming a given thinker or movement to be either a success or a failure. As Macey's book demonstrates, neither Fanon nor his ideas were widely known during his lifetime. ${ }^{3}$ Moreover, the central role accorded to his thought in postcolonial studies and African-American critical thought/activism in the decades since his death is balanced by indifference, even hostility, on the part of many in France, Martinique and Algeria, the three sites with which his work is most associated but where the celebrated Fanon of the Anglophone academy is now largely a mystery.

The article will also compare the interwar period, long marginalized as an era of 'failed' anti-colonial activism, with the 'successful' anti-colonial project of the period following the Second World War. In particular, it will focus on the career of the Senegalese militiant Lamine Senghor, one of the key anti-colonial figures of the mid-1920s, drawing out parallels between his writings and activism and those of Fanon. ${ }^{4}$ For, in certain respects, Senghor presents us with the opposite case to Fanon: while the latter's reputation soared after his death (albeit in uneven fashion), the Senegalese was celebrated in his lifetime but then drifted into obscurity after his death in 1927. A comparison of these two figures might help us to understand better the processes at work in deciding how and why a given thinker/activist is celebrated or decried as a success or a failure. As the historian of Francophone Africa Frederick Cooper has argued in another context (the collapse of a federal project linking 
France and Africa under the Fourth Republic), 'the failure [...] is explainable, but explainable does not mean that failure was inevitable and that the attempt is a minor detour along the path of history'. A similar desire to do justice to the complexity of the past is central to Macey's biography of Fanon and also motivates the present article. Macey's work is a model of how to respect both the ideas and 'l'expérience vécue' - a key term for Fanon that Macey rightly argues to be have been consistently mistranslated in English-language versions of his work of the biographical subject. ${ }^{6}$ Is Fanon a 'success' because the Front de libération nationale (FLN) eventually gained independence for Algeria? If so, does that mean that all anti-colonial movements prior to the Second World War were 'failures' simply because they did not achieve independence in their time? And, if we think about such things differently, might we develop a new genealogy of anti-colonial thought?

\section{Theory, activism and the iconography of anti-colonial revolution}

From his entry on to the political stage in late 1924 until his death three years later, Lamine Senghor was the most celebrated and feared black militant in France. A veteran of the First World War, he first emerged as an activist within the Union intercoloniale (UIC), an organization created by the Parti communiste français (PCF) to group together anti-colonial activists from across the empire. Then, in 1926, after an apparent break with the PCF, he created France's first genuinely popular black movement, the Comité de défense de la race nègre $(\mathrm{CDRN})$, drawn largely from the small working-class black communities in the ports and major towns across the country. It was in his capacity as President of the CDRN that he was invited to deliver a speech at the inaugural congress of the League against Imperialism (LAI) in early 1927. Although he wrote regular articles for the radical press and, in the final year of his life, published a remarkable, hybrid anti-colonial pamphlet, La Violation d'un pays, 
Senghor was primarily an activist and was celebrated as such. In this sense he was quite unlike Fanon, who, although he has always been associated with the Algerian Revolution, remained primarily a thinker. He never actually took up arms, nor did he even play a significant organizational role within the FLN: he was a propagandist whose writings sought to analyse and to inspire but did not engage with operational issues. He was in essence a behind-the-scenes figure while Senghor was a 'front man' for the movements with which he was involved.

Nevertheless, there are some striking similarities between the trajectories of these two figures: both served in the French army (Senghor in the First World War, Fanon in the Second); their wartime experience played a pivotal role in developing their consciousness of the injustices of the colonial system; ${ }^{7}$ and both men died very young, just as they appeared to be on the cusp of even greater success. Senghor had been gassed at Verdun in 1917 and had contracted tuberculosis; he died, aged just 38, in late 1927. This was just two years older than Fanon who died from leukaemia in relative obscurity in a US hospital in 1961. As often happens in such cases, their early deaths have created a mystique around both men which has obscured the realities of their lives. As David Macey notes: 'In some ways, the almost anonymous image of Fanon provides the basis for later identifications with and appropriations of Fanon, precisely because it is at once so ill-defined and so stereotypical. [...] Revolutionaries, it would seem, are destined for heroic anonymity. ${ }^{8}$

Their respective positions during their lifetimes can be seen through an examination of three images that celebrate anti-colonial alliances at two very distinct moments of the twentieth century, namely the mid-1920s and the mid-1950s: the first of these has understandably become an iconic image representing the process of intellectual and cultural decolonization; the second is a little-known photograph from a now largely forgotten anticolonial conference of the 1920s; while the third is a portrait from the same 1920s conference, 
which for a brief period became one of the most iconic and celebrated images of black anticolonial resistance.

The first image is the group photograph taken in the courtyard of the Sorbonne where the Premier Congrès des écrivains et artistes noirs was held in September 1956. As is often the case with such images, it is a surprise to discover that those upon whom posterity has looked most favourably often occupy a more peripheral position than might have been imagined. Pride of place in the group is given to the doyen, Jean Price-Mars (seated in the middle of the front row beside his wife), who had been given the role of Chairman of the congress, a reflection of both his status as a leading Haitian diplomat and his pioneering role as a thinker on black culture, the author of, amongst other works, Ainsi parla l'oncle (1928) on Haitian oral culture. As one might expect, Léopold Senghor and Aimé Césaire, two of the chief architects of Negritude, are positioned in the front two rows, while Alioune Diop, founder of the Présence Africaine publishing house and chief organizer of the event, is seated beside Price-Mars's wife. Fanon, however, whom those in the contemporary postcolonial field retrospectively assume to have been one of the 'stars' of the show, is in fact situated a few rows back, away from the core group of prominent Negritude/Présence Africaine figures, tucked away to one side, with a rather sullen, reticent expression on his face. Fanon was not part of the Présence Africaine stable; he was also deeply suspicious of Negritude. His speech, 'Racisme et culture', was eagerly anticipated by the few delegates who knew of his work but somewhat dreaded by Diop, who considered Fanon to be something of a firebrand and the delegate most likely to disregard the injunction to limit his discussion to cultural matters.

The congress took place at a time when violence was escalating in Algeria, where Fanon was working as a psychiatrist, but the speakers largely heeded Diop's call for them to focus exclusively on cultural matters. Although Fanon did not explicitly cross the line into 
politics, his speech was littered with veiled references to the situation in Algeria, as Macey notes:

When he turns to colonialism's creation of structures which are modelled on traditional structures but placed under colonial supervision, he is referring to Kabylia. [...] Fanon [refers] quite transparently to [...] frustrated attempts to win Algerian hearts and minds and to eradicate the FLN's organizational and political apparatus. ${ }^{9}$

In the aftermath, few of the newspaper accounts of the congress mentioned Fanon's speech and it certainly was not picked out as a highlight. It was the last time Fanon would speak in public in France and, just a few months later, he would leave his post and join the FLN struggle against the French as a propagandist, leaving Présence Africaine's discussions of Negritude far behind him. ${ }^{10}$ Ironically, then, the iconic group photograph taken at the Sorbonne in September 1956 locates Fanon within the broad cultural anti-colonialism of Negritude and Présence Africaine, which is, broadly speaking, the terrain he occupies within contemporary postcolonial theory. However, in terms of Fanon's lived experience, the 1956 congress was not the culmination of his political and intellectual evolution but rather a turning point: after 1956, it was not race and identity that would occupy the centre of his thought but rather the issue of how colonized peoples might overthrow Empire and create new, egalitarian nation states.

Three decades earlier, a similarly eclectic group had gathered at a very different type of congress for the inaugural meeting of the LAI, held in Brussels in February 1927. The LAI was a short-lived initiative designed to create a broad anti-colonial front drawing together nationalists and communists; this broad front is clearly visible in a group photo, which features Lamine Senghor at its centre. To Senghor's right is Eddo Fimmen, the influential Dutch trade unionist and head of the International Transport Workers' Union, while to his left is an unnamed general from the Kuomintang, the Chinese nationalist movement; and to the general's left is Jawaharlal Nehru, President of the Indian National Congress party who would, two decades later, lead his country to independence. The photograph places Senghor at the 
heart of this unified front against Empire. Indeed, the congress was initially heralded as a major success, although, within a year, the splits between communists and nationalists had effectively undermined the LAI as a coherent anti-colonial initiative - and within just a month of the congress, the Kuomintang had massacred their communist allies back in China.

Another well-known photograph from the era is in all likelihood a staged recreation of Senghor's speech to the Congress of the League Against Imperialism, which had enjoyed a resounding success. It was widely acknowledged by his contemporaries that Senghor was a passionate and skilled public speaker: even the reports compiled by agents of the Service de contrôle et d'assistance en France des indigènes des colonies (CAI) - the secret police of the Ministère des colonies recorded their grudging acknowledgement of this fact. ${ }^{11}$ Senghor had his audience in raptures, denouncing imperialism as a modern form of slavery and calling on the colonized peoples to unite with the workers of the world in a global revolution to overthrow the capitalist-imperialist system. His speech was almost immediately translated into English and published in various magazines and newspapers in the United States, often accompanied by this iconic image of anti-colonial resistance. ${ }^{12}$ The image might have become an interwar equivalent of Alberto Korda's iconic photograph of Che Guevara, but Senghor's death within a few months of the congress precipitated a decline into obscurity from which his reputation has never fully recovered. The black, anti-colonial movements that Senghor founded soon faltered, and as the world slipped inexorably towards war, his reputation waned, as did the significance of the anti-colonial movements of the interwar period.

Why, then, did Fanon's reputation sore after his death while Senghor's sank with little trace? Senghor's life and writings remain important precisely because they serve as a case study through which to explore the nature of anti-colonial thought and activism during the interwar years and to assess why the period is seen as one marked by the complete failure of anti-colonial thought. How and why has it happened that the careers and ideas of Messali 
Hadj (Algeria), Max Bloncourt (Antilles), Camille Saint-Jacques (Haiti) and even Ho Chi Minh (Vietnam) have rarely been evoked within the postcolonial field or, when they have, have been cast as mere precursors to later successful movements/figures? Revisiting the past does not provide simple answers for the present but it does allow us better to understand the history that helped to create our contemporary world and to understand the full complexity of the choices facing political actors in that past. Just as Fanon and the post-Second World War activists of the Bandung moment would seek to do, Senghor and his fellow activists attempted to give shape to new forms of global solidarity; their radicalism acts as an intriguing early twentieth-century illustration of the excitement and potential - but also the limitations - of attempts at building transnational solidarities, as activists harnessed the class-based struggle of the socialist/communist internationals and attempted to wed it to a global front against colonial oppression. Similar excitement and similar limitations would be evident in Fanon's era but, for many commentators, his career was a success. Is this judgement a response to Fanon's inherent qualities as a writer and activist or is it more a reflection of the political successes of his time? I will seek to provide some tentative answers to this question in the second half of this article.

\section{Tricontinentalism: the global politics of decolonization}

Much of the postcolonial debate about Fanon's work over the past two decades has focused on the relative importance that should be accorded to the two distinct periods of his brief writing career. As Macey notes, by the beginning of the twenty-first century, it was the Fanon of Peau noire, masques blancs who was regularly heralded (most notably by Homi Bhabha) as a worthy forefather of the 'identity politics' that came to dominate postcolonial studies as a field of inquiry: 'The Third Worldist Fanon was an apocalyptic creature; the post-colonial 
Fanon worries about identity politics, and often about his own sexual identity, but he is no longer angry' for Macey, this denial of Fanon's anger as a driving force was a betrayal of Fanon's evolution as a man and a thinker, as he goes on to observe: 'If there is a truly Fanonian emotion, it is anger. [...] It was a response to the condition and situation of those he called the wretched of the earth. ${ }^{13}$ Macey's biography succeeds in underlining Fanon's trajectory as a thinker who began by exploring issues of race and identity but who, later, was committed almost exclusively to the politics of anti-colonial nationalism. What led a Martiniquan psychiatrist who had loyally served France in the Second World War to join a treasonous fight again the French Republic? Fanon was highly conscious of the ambiguities and ambivalences produced by the colonial system but eventually decided that a consciousness of these factors would not, by itself, bring about change.

Senghor was also an angry young man and his brief period of activism was equally marked by a dual engagement with questions of race and anti-colonialism, although he reversed the trajectory embarked on by Fanon. As we have already seen, Senghor first emerged onto the political scene as a militant within the UIC. Although nominally an independent group run by and for representatives of the colonized peoples - Nguyen ai Quoc, the future Ho Chi Minh, was one of the most active members of the group in its early stages the UIC was in fact controlled by the PCF's Comite des études coloniales (CEC). In the columns of the UIC's newspaper, Le Paria, were to be found the most violent denunciations of empire of the period, although the word 'independence' itself was rarely mentioned. Senghor quickly became a mainstay of UIC activities and a regular contributor to Le Paria. He wrote about strikes in French West Africa, projecting black and white workers united against their capitalist bosses and condemning forced labour in the colonies as a new form of slavery. However, his most significant contribution was in seeking to forge alliances with 
representatives of other colonial movements, based on the principle that the transnational reach of empire must be met with a transcolonial front of anti-colonial resistance.

In late 1924 and throughout 1925, the PCF, responding to the Comintern's policy of building alliances with nationalist movements, carried out its most sustained anti-colonial campaign when it sought to organize resistance to the colonial war in the Rif mountains of Morocco. ${ }^{14}$ Senghor threw himself wholeheartedly into the campaign against the Rif War, speaking at countless rallies. He adopted the 'official' Comintern line and promoted an alliance between all those engaged in anti-colonial struggle. But, whereas the likes of Jacques Doriot (the PCF 'handler' in charge of the CEC) 'translated' the actions of the Rif rebels into a proto-communism, Senghor, in an article first published in Le Paria in June-July 1925, regards the sense of despair and oppression felt by the Islamic world as sufficient motivation in itself for their revolt:

Avec son hypocrisie habituelle, [l'impérialisme français] présente le succès riffain comme le prélude d'une croisade islamique contre les peuples chrétiens.

L'Islam, représenté par 300 millions d'esclaves, écrasés sous la botte des différents impérialismes européens, reçoit pour la circonstance le qualificatif de "Barbarie", tandis que le capitalisme européen devient la "Civilisation occidentale"15

The Rif war is here not the result of a clash of civilizations but rather the understandable resistance of a colonized people to external domination. In many respects, Senghor was more astute than Fanon in seeing that Islam could provide an identity around which resistance to Empire might be constructed, but he was excessively optimistic about the possibility of creating alliances between different anti-colonial groups.

Both men interpreted revolts that were motivated in large part by a sense of a shared religious and/or cultural identity as politically radical acts that would lead to a more equal world - and they were both largely wrong in their judgement. However, do these misjudgements mark them out as wholesale failures, as some critics have sought to argue? Or does what is important in their work lie in their attempt to imagine new forms of solidarity, 
whether correct or not in their political judgements? Is it the importance of their 'texts' and the ideas they introduced into the world that certain scholars and activists continue to appreciate? In the text-based world of the academy - particularly in the literary and cultural subjects in which Fanon's work has flourished - are success and failure judged according to the persuasiveness of the ideas irrespective of how successful they have proven in practice? Many of those who recall Fanon today are often likely to be inspired by the poetry of his call to create a 'new man' rather than by the perspicacity of his political judgements. For the academic world, his success lies largely in the realm of ideas; for militants, it lies in the inspiration and anger of his words. Either way, it would appear that we are judging his success on a discursive level.

As we have already seen, unlike Fanon, Senghor's engagement with race and identity occurred after his initial commitment to anti-colonial politics. After loyally serving the PCF and the UIC throughout the Rif campaign, Senghor had gradually come by early 1926 to resent the limited space devoted by the communist movement to black questions in general as well as to his own marginalized status in particular. He decided that in order to promote the interests of black people, it was necessary to create independent black organizations: in March 1926, with the creation of the CDRN, he apparently committed himself to the world of racial politics, although the reality, as we shall see below, was far less clear-cut.

\section{How to be black in a white world}

On 26 March 1926, Senghor officially registered his new association and embarked on a tour of France's port cities in order to meet members of the small working-class black community and to persuade them to join the CDRN. His skills as a public speaker, honed during the Rif campaign, served him well: by the summer of 1926 it was estimated by the agents of the 
Service de contrôle et d'assistance en France des indigènes des colonies (CAI) - the secret police of the Ministère des colonies - that he had recruited over 500 members from a black population numbered at fewer than $20,000 .{ }^{16}$

As Christopher Miller and Brent Hayes Edwards have shown in their analyses of CDRN writings, what is most original about the movement is its critical reflection on the language of race, its exploration of the modes of self-definition available to black people. ${ }^{17}$ In particular, Senghor's article 'Le Réveil des nègres', published in Le Paria in April 1926, constituted an intellectual 'manifesto' announcing the creation of his new movement, in which Senghor articulates a racial identity that is based not on shared racial characteristics but (as with the Islamic identity outlined in his article on the Rif War) on a shared sense of oppression:

Une des plus grosses questions du jour est celle du réveil des nègres.

[...] Les impérialistes [...] exploitent la division de castes et de tribus existant primitivement dans notre race, en divisant les nègres en trois espèces différentes : "Hommes de couleur", "Noirs" — tout court — et Nègres.

$[\ldots]$ être nègre, c'est n'être bon qu'à être exploité jusqu'à la dernière goutte de son sang ou être transformé en soldat pour la défense des intérêts du capitalisme envers et contre tous ceux qui oseraient gêner à son extension. ${ }^{18}$

In 1926, to call for 'le réveil des nègres' was immediately to evoke a set of ideas and a vocabulary that had been rendered popular by Marcus Garvey, who had consistently called for the black world to wake from its long sleep. The most striking aspect of CDRN's transnational translation of Garvey's ideas is their use of the term 'nègre' as a proud badge of self-identification, just as Garvey had proclaimed himself a 'Negro' (always with a capital 'N'). In an era when the term 'noir' was widely gaining prominence as a more dignified replacement for 'nègre', which was seen as derogatory and demeaning, Senghor and the CDRN deliberately choose 'nègre' as the term that encompasses all black people:

Nous [...] nous faisons honneur et gloire de nous appeler Nègres, avec un grand $N$ majuscule en tête. C'est notre race nègre que nous voulons guider sur la voie de sa libération totale du joug esclavagiste qu'elle subit. Nous voulons imposer le respect dû 
à notre race, ainsi que son égalité avec toutes les autres races du monde ; ce qui est son droit et notre devoir. ${ }^{19}$

While it is important to acknowledge differences in vocabulary, intellectual framework and the specific conclusions drawn, I would contend that Senghor is here occupying very similar ground to the Fanon of Peau noire, masques blancs. The term 'nègre' is deployed in the Sartrean sense that Fanon mobilized in his borrowings from Réflexions sur la question juive: it is an invention of the white world, an identity that has been imposed from outside. However, where Fanon calls on these identities to be deconstructed and abandoned in Peau noire, Masques blancs, Senghor calls on his fellow nègres - imagined almost exclusively as a masculine identity, again, in a fashion similar to Fanon - to embrace the name that has been imposed on them from outside. The 'nègre' is an individual who has been downtrodden and oppressed through slavery, colonialism, segregation: the terms 'noir' and 'homme de couleur' are seen merely as escape routes for educated blacks seeking a place in a dominant white society. The first step towards liberation is to embrace one's identity as a 'nègre', for that allows one to perceive the true nature of Western oppression of the black world; indeed, this might well be read as anticipating Fanon's position. For, unlike the Negritude thinkers who dominated in the period between the 1930s and the 1950s, neither Senghor nor Fanon believes in an 'authentic' black identity: their ultimate goal is the overthrow of all racial categories in the name of a wider egalitarian agenda.

The final highpoint in Senghor's career was the publication in 1927 of La Violation d'un pays. This brief volume relates in polemical fashion the bloody history of slavery and colonialism. Sometimes described as a brochure or a pamphlet, it is in fact a generically hybrid text that mixes the form of the fable with a highly didactic approach, utilising the political language of revolutionary communism; the text is also accompanied by five simple line drawings designed to reinforce the political message. This generic experimentation, as Brent Hayes Edwards has argued ${ }^{20}$ reveals an attempt to find a language and a form that 
would allow his critique of colonialism to find as wide an audience as possible; it is also a firm recognition that the anti-colonial struggle must also attempt to situate itself in the cultural domain.

La Violation d'un pays concludes with the overthrow of the colonial regime by a world revolution that liberates not only the colonies but also the metropolitan centre from the yoke of capitalist imperialism:

Le même jour, à la même heure, chez les bronzés, chez les jaunes et chez les « moins pâles », la révolution éclata de concert avec les citoyens pâles [...]. Les esclaves devinrent libres ! les citoyens de chaque pays dirigèrent le Gouvernement de leur état. Ils formèrent l'alliance fraternelle des pays libres. VIVE LA RÉVOLUTION!!! ${ }^{21}$

This resolution to the story obviously proved unrealistic in the context of the 1920s in Africa, but it acts, within the context of Senghor's story, as a form of ideological wish fulfilment: we might even describe it as the 'performance' of an international anti-colonialism. Some historians of the period have argued that independence was pretty much 'unthinkable' in the $1920 \mathrm{~s},{ }^{22}$ but the case of Senghor illustrates that the desire to overthrow Empire was fostered by many on the radical fringes of colonial society, even if the means to achieve independence escaped them. Are Senghor and his generation failures because they were unable to loosen the grasp of Empire from its colonial possessions? As Macey's work demonstrates, Fanon was not himself a successful revolutionary. He was not a keen military or political strategist who accomplished specific tasks in the name of independence: he was a theorist and propagandist, a man who sought both to analyse and to inspire. Like Senghor, he was a figure whose clarity of analysis and angry prose fuelled an imagination that sought nothing less than to create a new world order. In Les Damnés de la terre, his final published work, Fanon ends with a vision of a new world order and the creation of a new man, expressed in terms that recall Senghor's earlier utopian vision of a global anti-colonial revolution: 'Pour l'Europe, pour nous-mêmes et pour l'humanité, camarades, il faut faire peau neuve, developer une pensée neuve, tenter de mettre sur pied un homme neuf. ${ }^{, 23}$ 


\section{Conclusion}

The black internationalism of Lamine Senghor is a classic example of the transnational diasporic practice defined by Brent Hayes Edwards. ${ }^{24}$ Senghor's conception of race was inextricably tied up with his embrace of communism, as the most likely source of the revolution that would lead to the liberation of black people around the world. Unlike his contemporary George Padmore, ${ }^{25}$ he was not forced to make a choice between panAfricanism and communism but appeared to believe that these two ideologies could complement each other in the quest for black liberation. The experience of his successor as leader of the LDRN, Tiémoko Garan Kouyaté, constantly in conflict with the PCF hierarchy over the next decade, warns us that Senghor may well have met the same fate and been forced to make the same choice as Padmore. However, on the evidence of his activism and his writings, it can be argued that Senghor is best situated within a lineage of left-leaning panAfricanists - from his compatriot Ousmane Sembene to C. L. R. James and of course Fanon for whom anti-colonialism, pan-Africanism and Marxism remained throughout their lives crucial to constructing a transnational politics as well as transnational forms of identification. $^{26}$

The elevation of Fanon or Senghor as prophets of decolonization or their dismissal as misguided ideologues are perhaps understandable but neither approach does justice to the constraints and possibilities of the times within which they lived. David Macey's biography provides a brilliant analysis of the complexity and the contradictions in Fanon's writing, as he sought to reconcile issues of race, class and empire in ways that that are highly original but that also belong to a long and rich tradition of engagement with such questions. Fanon was not uniquely successful as a theorist nor was he unusually blind to those factors that did not 
suit his argument. He was, as Macey argues, a man struggling not to only to make sense of his world but also to change it, working within the inherent constraints of his times and his own cultural and intellectual background. Above all, Fanon was an angry man who sought to channel that anger to change the world and not simply to define it. He took sides with all of the compromises and blind spots that such a choice entails. Where some critics have read Fanon 'backwards' so as to make light of his decision to 'take sides', Macey seeks to understand that choice in terms that resonate with Timothy Brennan's work on Amilcar Cabral:

The dialectic of colonizer and colonized was simply not supposed to represent either a sociological explanation or a nuanced cultural model. It was itself a focus-that is, a careful exclusion. He was not lumping difference together, nor was he unaware of multiple communities with their disparate interests. He did not emphasize the disparate because it would not then, in that project, have led to more than the impossibility of doing. ${ }^{27}$

Indeed, one might find in the impulse to do justice to the anger at the heart of Fanon's life and writings a fitting tribute to the life and writings of David Macey, for whom oppression and marginalization were never mere theoretical abstractions.

\section{Notes}

1. See Christopher L. Miller, Theories of Africans: Francophone Literature and Anthropology in Africa (Chicago: University of Chicago Press, 1990); Neil Lazarus, 'Disavowing Decolonization: Fanon, Nationalism, and the Problematic of Representation in Current Theories of Colonial Discourse', Research in African Literatures, 24.4 (1993), 70-98.

2. C. L. R. James, 'Preface to the First Edition', in The Black Jacobins: Toussaint Louverture and the San Domingo Revolution [1938] (London: Allison \& Busby, 1980), pp. ix-xi (p. x).

3. David Macey, 'Forgetting Fanon, 'Remembering Fanon', in Frantz Fanon: A Biography, $2^{\text {nd }}$. ed. (London: Verso, 2012), pp. 1-30. 
4. For an overview of Senghor's career as well as his collected writings, see Lamine Senghor, La Violation d'un pays et autres écrits anticolonialistes, ed. by David Murphy (Paris: L'Harmattan, 2012). For a discussion of Senghor's emergence as a public figure in the context of the infamous Maran-Diagne trial in November 1924, see Alice L. Conklin, 'Who Speaks for Africa? The René Maran-Blaise Diagne Trial in 1920s Paris', in The Colour of Liberty: Histories of Race in France, ed. by Sue Peabody and Tyler Stovall (Durham, NC: Duke University Press, 2003), pp. 302-37. The best overview of interwar black movements in France remains Philippe Dewitte, Les Mouvements nègres en France 1919-39 (Paris: L'Harmattan, 1985).

5. Frederick Cooper, 'From Imperial Inclusion to Republican Exclusion? France's Ambiguous Postwar Trajectory', in Frenchness and the African Diaspora: Identity and Uprising in Contemporary France, ed. by Charles Tshimanga, Didier Gondola and Peter J. Bloom (Bloomington, IN: Indiana University Press, 2009), pp. 91-119 (p. 117).

6. In his opening chapter, 'Forgetting Fanon, Remembering Fanon', Macey rightly bemoans the problematic nature of many of the early translations of the Martiniquan's work. In particular, the translation of the title of the fifth chapter of Peau noire, masques blancs, 'L'Expérience vécue de l'homme noir', as 'The Fact of Blackness' was emblematic of the misrepresentation of his ideas in their English versions. See Macey, Frantz Fanon, p.26.

7. On the role of African troops in the First World War, see Marc Michel, Les Africains et la grande guerre: l'appel à l'Afrique (1914-1918) (Paris: Karthala, 2003).

8. Macey, Frantz Fanon, pp.17-18.

9. Macey, Frantz Fanon, p. 285.

10. See Macey, Frantz Fanon, p. 289.

11. For the full text of Senghor's Brussels speech, see La Violation d'un pays, pp. 55-62. 
12. See, for example, R. N. Baldwin, 'The Capital of the Men without a Country', The Survey, 1 August 1927, 460-8.

13. Macey, Frantz Fanon, p. 27.

14. The PCF-led campaign against the war in the Rif was a flawed, transient but still quite remarkable attempt to forge transnational alliances against Empire. For a balanced discussion of the campaign, see David H. Slavin, 'The French Left and the Rif War, 192425: Racism and the Limits of Internationalism', Journal of Contemporary History, 26.1 (1991), 5-32.

15.Senghor, 'Les Riffains ne sont pas seuls', in La Violation d'un pays, pp. 35-9 (p. 36).

16. See David Murphy, 'Introduction', in Senghor, La Violation d'un pays, pp. vii-lxi (p.xli).

17. See Christopher L. Miller, Nationalists and Nomads: Essays on Francophone African Literature and Culture (Chicago: University of Chicago Press, 1998); Brent Hayes Edwards, The Practice of Diaspora: Literature, Translation and the Rise of Black Internationalism (Cambridge, MA: Harvard UP, 2003).

18. Senghor, 'Le Réveil des nègres', in La Violation d'un pays, pp. 41-3 (p. 41).

19. Ibid., p. 43.

20. See Edwards, The Practice of Diaspora, pp. 225-40.

21. Senghor, La Violation d'un pays, pp. 29-30.

22. See, in particular, Dewitte, Les Mouvements nègres en France, 1919-1939.

23. Frantz Fanon, Les Damnés de la terre [1961] (Paris: Gallimard, 1991), p. 376.

24. See Edwards, The Practice of Diaspora.

25. George Padmore, Panafricanisme ou communisme? La prochaine lutte pour l'Afrique (Paris: Présence Africaine, 1960).

26. When Macey published the first edition of his biography, there was surprisingly little critical material on the history of what has come to be known as 'black France', a situation 
that has evolved radically over the past decade with a series of landmark publications including: Dominic Thomas, Black France: Colonialism, Immigration and Transnationalism (Bloomington, IN: Indiana University Press, 2006); Pap Ndiaye, La Condition noire: essai sur une minorité française (Paris: Calmann-Lévy, 2008); Gradhiva. Special issue: 'Présence Africaine. Les Conditions noires: une généalogie des discours', 10 (2009); Pascal Blanchard, et al. La France Noire: trois siècles de presences (Paris: La Découverte, 2011).

27. Timothy Brennan, At Home in the World: Cosmopolitanism Now (Cambridge, MA: Harvard University Press, 1997), p. 3. 